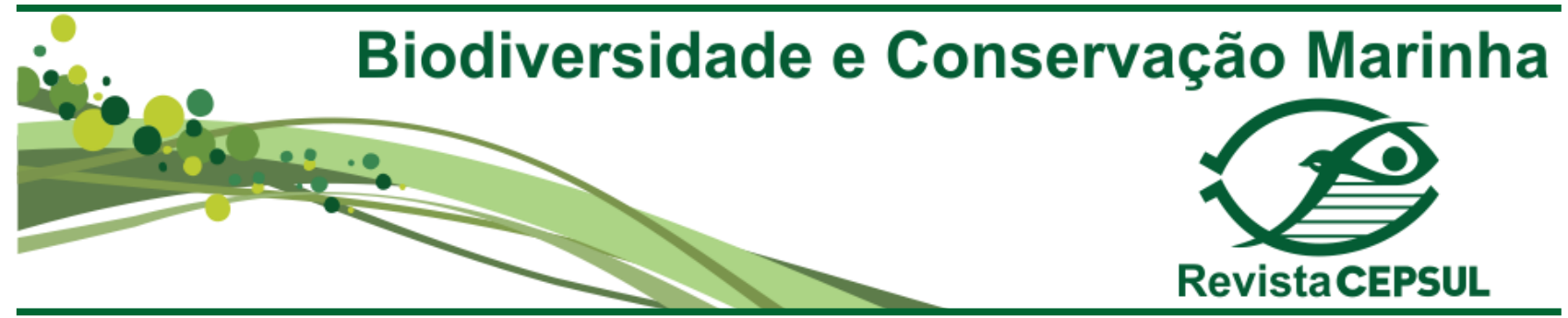

ARTIGO CIENTÍFICO

\title{
Fish species richness in shallow environments of the Island of
}

\author{
Santa Catarina, Southern Brazil
}

\author{
André Pereira Cattani ${ }^{1}$, Olímpio Rafael Cardoso ${ }^{1}$, Gisela Costa Ribeiro ${ }^{2}$, Marcelo Soeth ${ }^{1}$, \\ Maurício Hostim-Silva ${ }^{3}$, Leandro Clezar ${ }^{2}$, Helen Audrey Pichler 3 \& Henry Louis Spach ${ }^{1}$
}

${ }^{1}$ Centro de Estudos do Mar, Universidade Federal do Paraná - UFPR, Avenida Beira Mar, s/n, Pontal do Sul, CEP - 83255-976, Pontal do Paraná, PR, Brasil, cattani.andre@gmail.com; rafael.bioufrgs@gmail.com; marcelosoeth@yahoo.com.br; henry@ufpr.br;

${ }^{2}$ Laboratório de Ictiologia, Núcleo de Estudos do Mar, Universidade Federal de Santa Catarina - NEMAR/UFSC, Trindade, CEP 88040-9oo - Florianópolis, SC - Brasil, gisela.ribeiro@ufsc.br; leoclezar@gmail.com;

3 Departamento de Ciências Agrárias e Biológicas, Centro Universitário Norte do Espírito Santo, Universidade Federal do Espírito Santo - CEUNES/UFES, Rodovia BR 101 Norte, Km. 6o, Bairro Litorâneo, CEP - 29932540 , São Mateus, ES, Brasil, mhostim@gmail.com; pichler.helen@gmail.com.

\section{Submetido em: 14/11/2017; Aceito em: 26/o2/2018; Publicado em: 22/o3/2018}

\begin{abstract}
The Island of Santa Catarina is a mosaic of ecosystems of great importance for fish fauna, highlighting the presence, in the same island, of estuaries, lagoons, mangroves, rocky shores and sandy beaches. This study aimed to compare, based on species richness, fish assemblages between different ecosystems. Between 1981 and 2011, there were collected a total of 165 taxa of fish, distributed in 54 families, in six sampling sites, using casting net, sweep net, beach trawl and gill net. According to the species accumulation curve, that show the increase of the number of different species with the increase of the number of samples, for all sites, the curves of species recorded followed patterns similar to curves obtained by the Jacknife index. However, the number of species has stabilized only for samples collected in Saco dos Limões, Itacorubi Mangrove and Ratones Mangrove. Comparing the mean values of richness between sites, the highest mean value was found in Saco dos Limões, followed by Índio Beach, Conceição Lagoon, North Bay, Itacorubi and Ratones Mangroves. Using the list of species as reference, despite the differences in abundance and richness between sites, the taxonomic structure is similar between sampling sites, which supports the hypothesis that the assemblages are occurring in all sites and the differences are primarily related to the patterns of reproduction and recruitment of species and secondarily influenced by abiotic factors, especially the temperature and salinity.
\end{abstract}

Palavras-chave: Taxonomic Structure, Florianópolis, Fish fauna, Coastal Mosaic. 


\begin{abstract}
Resumo. Riqueza de espécies de peixes em ambientes pouco profundos da ilha de Santa Catarina, Sul do Brasil. A Ilha de Santa Catarina é um mosaico de ecossistemas de grande importância para a fauna de peixes, destacando a presença, na mesma ilha, de estuários, lagoas, manguezais, costões rochosos e praias arenosas. Este estudo objetivou comparar, com base na riqueza de espécies, as associações de peixes entre diferentes ecossistemas. Entre 1981 e 2011, foi coletado um total de 165 taxa de peixes, distribuídos em 54 famílias, em seis áreas amostrais, usando tarrafa, puça, rede de arrasto de praia e rede de emalhe. De acordo com a curva de acumulação de espécies, que mostra o aumento do número de diferentes espécies com o aumento do número de amostras, para todos os sítios, as curvas das espécies registradas seguiram padrões semelhantes às curvas obtidas pelo índice de Jacknife. Comparando os valores médios de riqueza entre sítios, o maior valor médio foi encontrado em Saco dos Limões, seguido pela Praia do Índio, Lagoa da Conceição, Baía Norte, Manguezal do Itacorubi e Manguezal de Ratones. Utilizando a lista de espécies como referência, apesar das diferenças de abundância e riqueza entre os sítios, a estrutura taxonômica é semelhante entre os locais de amostragem, o que suporta a hipótese de que as assembleias estão ocorrendo em todos os locais e as diferenças estão principalmente relacionadas aos padrões de reprodução e recrutamento de espécies e secundariamente influenciado por fatores abióticos, especialmente a temperatura e a salinidade.
\end{abstract}

Palavras-chave: Estrutura Taxonômica, Florianópolis, Fauna de Peixes, Mosaico Costeiro.

\section{Introduction}

Comparisons of diversity patterns within each site and comparisons with other sites had the main goal to evaluate the similarities and differences in each area, disregarding the specific merits of species and modes of use of each environment. In this sense, in theoretical ecology, there are two divergent schools of thought about the patterns of diversity: Niche Theory and Neutral Biodiversity Theory.

The Niche theory, consolidated by Hutchinson (1957), raises a hypothesis that each species has an ecological role in the environment, in terms of predation and intra and interspecific competition (Begon et al., 2007). Recently, in studies on estuarine fish, the niche concept is applied to the classification of species into functional guilds and estuary use guilds (Elliot et al., 2007). This type of classification allows the distinction of fish assemblages beyond the taxonomic and phylogenetic classification, considering the different types of environmental uses. However, some classifications are not consensual, which can generate misstatements, in which a species can be classi- fied differently by several authors (Passos et al., 2013).

More recently, in contrast to the Niche theory, another hypothesis arises to explain the species occurrence patterns. The Neutral Theory of Biodiversity by Hubbell (2001) proposes that the species are trophically and functionally equivalent, with ecological properties identical within an assemblage or community (Cassemiro \& Padial, 2008). In this case, the number of species in a given assemblage is ruled by random processes, whose dominances among species are influenced by the migration rates from an assemblage to another. Thus, regardless of which theory is more appropriate to explain the patterns of diversity in the study sites, it was not the objective of this work to test, validate or disprove either theory, but rather compare the sites and evaluate the similarities between them.

\section{Material and methods}

\section{Study area}

The island of Santa Catarina $\left(28^{\circ} 37^{\prime} \mathrm{S}\right.$; 
$48^{\circ} 27^{\prime} \mathrm{W}$ ) is located parallel and adjacent to the continental margin, with elongated shape and directed towards N-NE/S-SW, and occupies an area of $431 \mathrm{~km}^{2}$, surrounded by $180 \mathrm{~km}$ of coast, on the limit of the subtropical region (Sierra de Ledo, 1997). It is an insular environment composed of diverse ecosystems such as mangroves, lagoons, sandy beaches and rocky shores. Six water bodies, represented by the lagoons of Conceição and Peri $\left(19.2 \mathrm{~km}^{2}\right.$ and $5.1 \mathrm{~km}^{2}$, respectively), the first permanently connected to the sea and the second containing fresh water, along with temporary small lagoons (Chica, Pequena, Leste, Ponta das Canas and Campeche) with $0.3 \mathrm{~km}^{2}$ surface area, occupy $6.5 \%$ of the surface of the island (Sierra de Ledo, 1997).

According to the Köppen climate classification, the region has a humid subtropical climate (Cfa), the rainfall has a clear seasonality, with the rainy season in the months of spring and summer, with a monthly average of $149 \mathrm{~mm}$, and the dry season in months of fall and winter, with a monthly average of $95 \mathrm{~mm}$ (MPB, 2013).

The prevailing wind regime on the island is related to the action of Tropical Atlantic and Polar Atlantic air masses that generate winds from the north and south quadrants, respectively (Castilhos \& Gré, 1997). According to these authors, the dominant waves come mainly from the northeast, southeast and south, with the largest swells from the south. Regarding the tide, inside the bays in the area near the island of Santa Catarina, it is classified as semidiurnal, with an average range of $0.52 \mathrm{~m}$ (Soriano-Sierra, 1997).

The study area corresponds to the following environments belonging to the Island of Santa Catarina:

- North Bay (Figure 1, point A), with 146 $\mathrm{km}^{2}$ of surface and predominantly oceanic characteristics, whose physicochemical parameters vary mainly according to the region's rainfall regime (Cerutti, 1996). According to Campos, 2011, there are predominance of fine sediments, represented in the granulometry by medium to thick clays and very fine to thick silts;

- Saco dos Limões (Figure 1, point B), a cove with depths varying from $1 \mathrm{~m}$ in the southern portion to $10 \mathrm{~m}$ in the northern portion, with the predominance of fine sediments and fractions of sandy sediments associated to shoals near the Tavares river mangrove (Cartagena et al., 2011);

- Ratones Mangrove (Figure 1, point C), characterized as a more preserved environment, located north-west of Santa Catarina Island on the North Bay, occupying, in the estuarine part of the Ratones River, an area of 7.30 $\mathrm{Km}^{2}$ (Simonassi et al., 1997). Its surface is drained by several rivers and streams, being the Ratones River the main one of the hydrographic basin;

- Itacorubi Mangrove (Figure 1, point D), a more anthropized environment due to its location close to the urban network and the use of this place for the deposit of municipal waste, including domestic and hospital waste. It has an area of $1.42 \mathrm{~km}^{2}$ (Soriano-Sierra, 1993 apud Souza-Sierra et al., 1997);

- Índio Beach (Figure 1, point E), is characterized as sheltered from waves (Jackson et al., 2002). Its tidal regime is semidiurnal with an average amplitude of $0.52 \mathrm{~m}$ (SorianoSierra \& Sierra de Ledo, 1998). There is a high prevalence of salinities, generally above thirty, and a thermal amplitude of 16 to $28^{\circ} \mathrm{C}$ (Maciel et al., 2010; Simonassi et al., 2010);

- Conceição Lagoon (Figure 1, point F), located in the center-east of the Island, has an area of $19.2 \mathrm{~km}^{2}$, and depth ranging from 0.5 $\mathrm{m}$ in the sandbanks to $8.8 \mathrm{~m}$ in the canals (Muehe \& Gomes JR, 1999). It presents predominance of sandy sediments in the marginal and silty parts in the most central and deep parts (Muehe \& Gomes JR, 1999).

\section{Sampling design}

In the North Bay, seasonal samplings were conducted in January, April, July and October of 2005. On board a wooden boat of 6 meters equipped with an $18 \mathrm{Hp}$ diesel engine, bottom trawls were towed for 30 minutes in six predefined areas in the North Bay (Figure 1, 


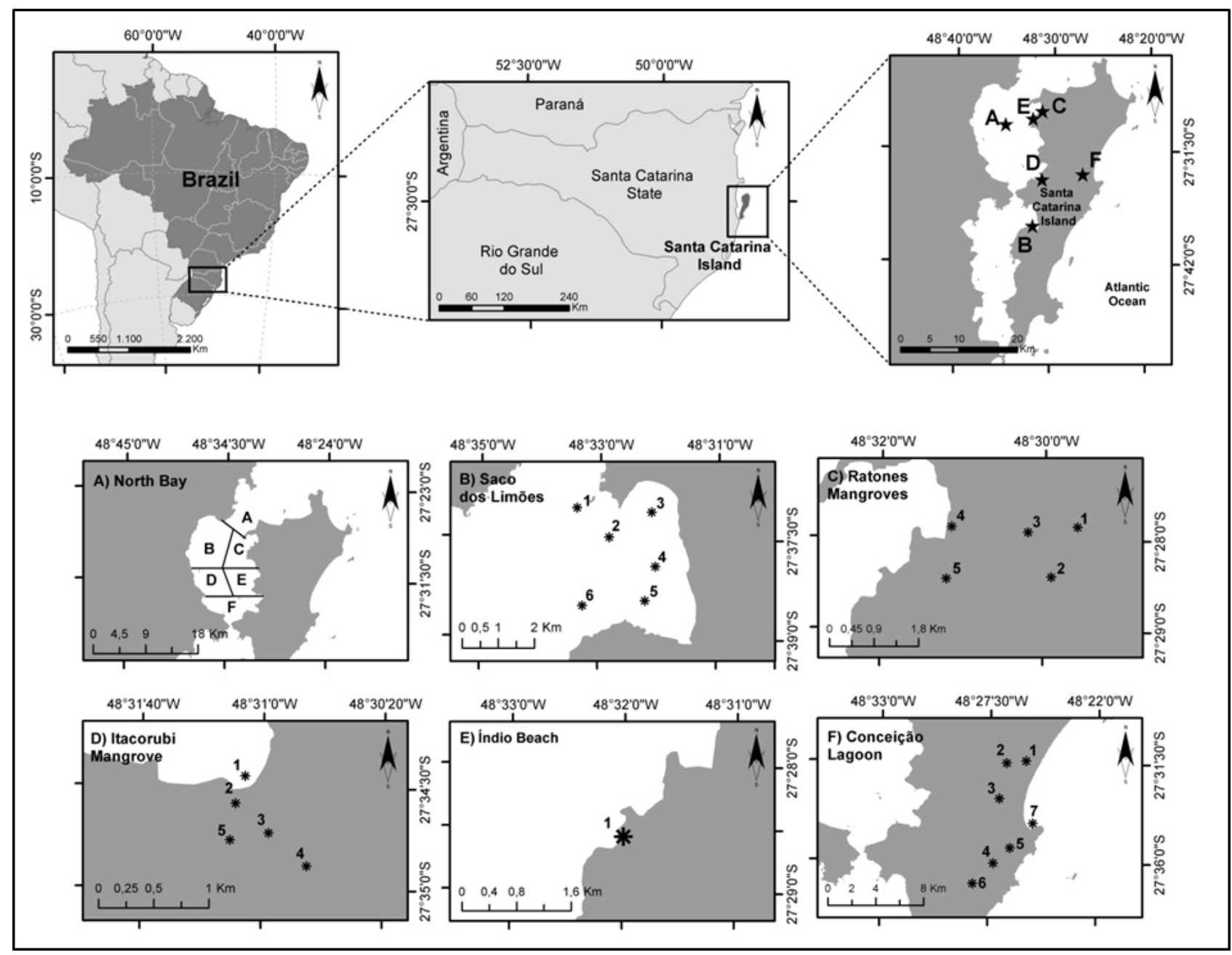

Figure 1. Map with the location of sampling sites in the island of Santa Catarina. A) In the North Bay, seasonal samplings were conducted in 2005; B) In the Saco dos Limões, fish were sampled between February 2001 and December 2003; C) Data of the Ratones Mangroves were obtained by two samplings at different times. The first took place from September to December 1997, January-December (except for February) 1998 and from February to May 1999; D) In the Itacorubi Mangrove, monthly samples between 1986 and 1989; E) In the Índio Beach, used data from Ribeiro et al. (2014), fish were collected monthly between December 2010 and November 2011; F) In the Conceição Lagoon, samples were taken between 1981 and 1993.

point A).

In the Saco dos Limões, fish were sampled day and night every two months, between February 2001 and December 2003, in six sampling sites (Figure 1, point B). At each sampling site, double trawls were deployed for 10 minutes each, using one trawl with $4.5 \mathrm{~m}$ long, $7.5 \mathrm{~m}$ top and $9 \mathrm{~m}$ bottom and meshes from 12 to $14 \mathrm{~mm}$ between opposite knots. Fish collection of both nets towed simultaneously was considered as a sample.

In the Itacorubi Mangrove, monthly samples were taken during 32 months, between 1986 and 1989 in five distinct sites (Figure 1, point D). In each site and month, 30 fishing haul were made with the help of cast nets with meshes of 10 and $20 \mathrm{~mm}$ between adjacent knots, 15 hauls for each net. On the banks of the rivers, we used sweep net $10 \mathrm{~mm}$ mesh between adjacent knots. Besides, at the confluence of the rivers that cross this mangrove, we also used a gill net, with two side nets $150 \mathrm{~mm}$ mesh size and a central net $30 \mathrm{~mm}$ mesh size, both between adjacent knots.

Data of the Ratones Mangroves were obtained monthly in five sites (Figure 1, point C) from September to December 1997, January -December (except for February) 1998 and from February to May 1999, totaling 19 months of collection. In each month and site three cast 
nets with the same diameter and different mesh sizes $(45,60$ and $65 \mathrm{~mm}$ between adjacent knots, respectively) were cast 10 times, totaling 30 throws. Ten casts of a sweep (10 $\mathrm{mm}$ mesh size) were also used on the margins.

In the Conceição Lagoon (Figure 1, point F), samples were taken between 1981 and 1993, in 63 months and seven sampling sites distributed in the north, central and south sectors. At each site, fish were collected with cast nets of different mesh sizes, sweep net and beach seine net.

Still, we also used data from Ribeiro et al. (2014) on fish collected at Índio Beach, in the northwestern of the island of Santa Catarina, on the shore of the North Bay (Figure 1, point E). In this study, fish were collected monthly between December 2010 and November 2011 in the first neap tide of each month with the help of a Fyke net (capéchade). The net consisted of a barrier (20 m long, $2 \mathrm{~m}$ high, $13 \mathrm{~mm}$ mesh size) and three trap nets, mesh ranging from 13 to $6 \mathrm{~mm}$. The fishing gear has operated for 48 hours with inspections held at dawn and dusk, totaling four samples in total, two diurnal and two nocturnal.

\section{Statistical analysis}

All analyzes were calculated using the statistical package PRIMER, 6.1.12 (Clarke \& Gorley, 2006) \& PERMANOVA+ (Anderson et al., 2008). The comparison between the sites was based on species richness. In this way, in addition to comparing the sites, we also compared the environments: lagoon, represented by the data of Conceição Lagoon; bay (estuarine) with data from the North Bay and Saco dos Limões; mangrove (Itacorubi and Ratones) and beach (Índio).

To evaluate the representativeness in the number of species in each site, we constructed with data of abundance of every month and year, species accumulation curves, that show the increase of the number of different species with the increase of the number of samples. In addition to the observed values of the species accumulated in the samples, we drawn a curve based on the first order Jacknife index (Colwell \& Coddington, 1994). This index $(S)$ estimates richness based on the number of species occurring only in a sample.

$$
S=S_{O B S}+L\left(\frac{n-1}{n}\right)
$$

where $S_{O B S}=$ number of species observed; $L=$ sample and $n=$ number of species.

Thus, it is assumed that the curves drawn with the observed data and modeled data follow the same pattern and if both curves reach a stabilization, then the number of species in each site is representative of the whole, allowing comparison between sites. However, it was not considered any differences arising from the selectivity of the different fishing gears used in the samplings.

To test the difference between the sites, environments, and seasons, a PERMANOVA was run, using the following complex model:

$$
\begin{aligned}
& X=\mu+E s+A m+L o(A m)+E s^{*} A m+ \\
& E s^{*} L o(A m)+e
\end{aligned}
$$

where $X=$ dependent variable; $\mu=$ mean; $E s=$ season, $A m=$ environment, $L o=$ site; $\mathrm{e}=$ error.

This model was used to test differences in species richness between the seasons (summer, winter, fall and spring), between environments (bay, mangrove, lagoon and beach) and between sites (North Bay, Saco dos Limões, Itacorubi Mangrove, Ratones Mangrove, Conceição Lagoon and Índio Beach).

The factors season (Es) and environment $(\mathrm{Am})$ were considered as fixed and the factor site $(\mathrm{Lo})$ was considered as random, nestled in the factor environment. Due to differences in sampling effort between each site, samples were standardized, considering the presence/absence of species in the four seasons.

The PERMANOVA was run with a similarity matrix based on the Sorensen index, spe- 
cific to presence/absence data (Clarke \& Warwick, 1994). Also, 9999 permutations were made. A canonical analysis of principal coordinates (CAP) was performed and the vectors (species) were plotted based on the Spearman correlation of 0.6 (Clarke \& Warwick, 1994).

The indices Average Taxonomic Distinctness and Variation in Taxonomic Distinctness, which allow to evaluate the differences in the taxonomic structure of the species, better reflecting the biodiversity and presenting greater robustness in relation to the variations in the sample effort, were calculated with presence/absence data of each site. Funnel-shaped charts and biplot graphs were constructed for visual presentation of results (Clarke \& Warwick, 1994).

\section{Results}

There were collected a total of 165 taxa of fish, distributed in 54 families in the six sampling sites (Table 1). The families with higher richness were, in descending order, Sciaenidae (19 species), Carangidae (13), Engraulidae and Serranidae (10 each), Paralichthyidae (9), Gerreidae (8), Tetraodontidae (7), Gobiidae and Haemulidae (6 each), Clupeidae and Lutjanidae (5 each), Achiridae and Ariidae (4 each) and Atherinopsidae, Blenniidae, Monacanthidae and Mugilidae (3 each). The other families had only one species each (Table 1).

Of the 165 taxa of fish identified in this research, 17 are present in all environments. As for the dissimilarity between the environments, 25 taxa are present exclusively in the Conceição Lagoon, 14 exclusive taxa in the Saco dos Limões, 10 taxa in the Índio Beach, 7 taxa in the North Bay, 4 taxa in the Itacorubi Mangrove and only 3 taxa in the Ratones Mangrove (Table 1). However, it is worth remembering that for this work, the collections were carried out in different periods with different gear, as already described in material and methods.

According to the species accumulation curve based on Jackknife index, it was observed that, for all sites and as expected, the recorded species curves followed patterns simi- lar to curves obtained by the index (Figure 2). However, the number of species has stabilized only for samples collected in Saco dos Limões (LIM), Itacorubi Mangrove (ITA) and Ratones Mangrove (RAT). For other sites, although no stabilization has occurred, the curves follow a very close pattern (Figure 2).

Comparing the mean values of species richness between sites, environments throughout the seasons, PERMANOVA detected significant differences between environments and sites (Table 2). In the paired test (Pairwise PERMANOVA) within each environment, there were significant differences only within the environment bay that correspond to North Bay and Saco dos Limões (p-value = 0.0295). Considering the sites, a higher mean species richness was found in the Saco dos Limões (mean \pm SEM; $59.75 \pm 2.5$ ), followed by Índio Beach (55.7 \pm 2.67), Conceição Lagoon (52.25 \pm 6.4 ), North Bay (45 \pm 2.48$)$, Itacorubi Mangrove $(34.5 \pm 3.17)$ and Ratones Mangrove (30.75 \pm 3.84) (Figure 3).

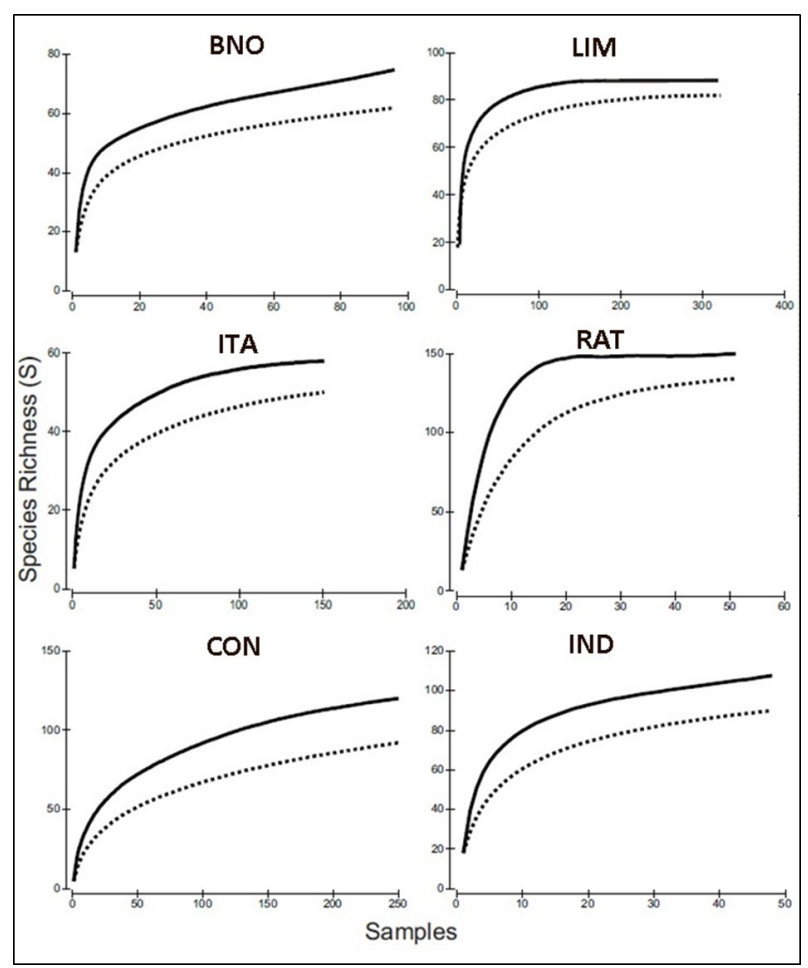

Figure 2. Species accumulation curve for species sampled in North Bay (BNO), Saco dos Limões (LIM), Itacorubi Mangrove (ITA), Ratones Mangrove (RAT), Conceição Lagoon (CON) and Índio Beach (IND). Comparison of observed values (dashed line) with values given by the Jacknife index (solid line). 
Table 1. Occurrence of families and species of fish collected in North Bay (BNO), Saco dos Limões (LIM), Itacorubi Mangrove (ITA), Ratones Mangrove (RAT), Conceição Lagoon (CON), and Índio Beach (IND) island of Santa Catarina, southern Brazil.

\begin{tabular}{|c|c|c|c|c|c|c|c|}
\hline Family & Species & BNO & LIM & ITA & RAT & CON & IND \\
\hline \multirow{4}{*}{ ACHIRIDAE } & Achirus declivis Chabanaud, 1940 & 1 & O & O & O & O & $\mathrm{O}$ \\
\hline & Achirus lineatus (Linnaeus, 1758) & 1 & 1 & 1 & 1 & 1 & 1 \\
\hline & Catathyridium garmani (Jordan, 1889) & $\mathrm{O}$ & 1 & 0 & $\mathrm{O}$ & $\mathrm{O}$ & 0 \\
\hline & Trinectes paulistanus (Miranda Ribeiro, 1915) & 1 & $\mathrm{O}$ & $\mathrm{o}$ & $\mathrm{o}$ & $\mathrm{O}$ & $\mathrm{O}$ \\
\hline \multirow{4}{*}{ ARIIDAE } & Cathorops spixii (Agassiz, 1829) & $\mathrm{O}$ & $\mathrm{O}$ & 1 & o & $\mathrm{O}$ & 1 \\
\hline & Genidens barbus (Lacepède, 1803) & 1 & 1 & 1 & 1 & o & 1 \\
\hline & Genidens genidens (Cuvier, 1829) & 1 & 1 & 1 & 1 & 1 & 1 \\
\hline & Genidens machadoi (Miranda Ribeiro, 1918) & $\mathrm{O}$ & $\mathrm{O}$ & $\mathrm{o}$ & $\mathrm{o}$ & $\mathrm{O}$ & 1 \\
\hline \multirow{3}{*}{ ATHERINOPSIDAE } & Atherinella brasiliensis (Quoy \& Gaimard, 1825) & $\mathrm{O}$ & $\mathrm{O}$ & 1 & 1 & 1 & 1 \\
\hline & Odontesthes argentinensis (Valenciennes, 1835) & $\mathrm{O}$ & o & o & o & o & 1 \\
\hline & Odontesthes bonariensis (Valenciennes, 1835) & $\mathrm{O}$ & $\mathrm{o}$ & o & o & 1 & $\mathrm{O}$ \\
\hline BATRACHOIDIDAE & Porichthys porosissimus (Cuvier, 1829) & 1 & 1 & o & o & o & 1 \\
\hline \multirow{2}{*}{ BELONIDAE } & Strongylura marina (Walbaum, 1792) & o & o & 1 & o & 1 & 1 \\
\hline & Strongylura sp. & $\mathrm{o}$ & o & $\mathrm{o}$ & o & 1 & 1 \\
\hline \multirow{3}{*}{ BLENNIIDAE } & $\begin{array}{l}\text { Hypleurochilus fissicornis (Quoy \& Gaimard, } \\
\text { 1824) }\end{array}$ & $\mathrm{O}$ & $\mathrm{O}$ & $\mathrm{O}$ & o & 1 & 0 \\
\hline & Parablennius pilicornis (Cuvier, 1829) & $\mathrm{o}$ & o & 0 & 1 & 1 & 0 \\
\hline & Scartella cristata (Linnaeus, 1758) & o & o & o & o & 1 & 0 \\
\hline BREGMACEROTIDAE & Bregmaceros atlanticus Goode \& Bean, 1886 & $\mathrm{O}$ & o & o & o & 1 & $\mathrm{O}$ \\
\hline \multirow{13}{*}{ CARANGIDAE } & Caranx hippos (Linnaeus, 1766) & O & O & 1 & o & 1 & O \\
\hline & Caranx latus Agassiz, 1831 & o & 1 & o & o & 1 & 0 \\
\hline & Chloroscombrus chrysurus (Linnaeus, 1766) & 1 & 1 & o & o & o & 1 \\
\hline & Hemicaranx amblyrhynchus (Cuvier, 1833) & o & o & o & o & o & 1 \\
\hline & Oligoplites palometa (Cuvier, 1832) & $\mathrm{O}$ & o & 1 & 1 & 1 & 1 \\
\hline & Oligoplites saliens (Bloch, 1793) & $\mathrm{O}$ & 1 & 1 & o & o & 1 \\
\hline & Oligoplites saurus (Bloch \& Schneider, 1801) & 1 & 1 & 1 & 1 & 1 & 1 \\
\hline & Selene setapinnis (Mitchill, 1815) & 1 & 1 & o & o & o & o \\
\hline & Selene vomer (Linnaeus, 1758) & 1 & 1 & 1 & o & 1 & 1 \\
\hline & Trachinotus carolinus (Linnaeus, 1766) & 1 & 1 & o & o & 1 & 1 \\
\hline & Trachinotus falcatus (Linnaeus, 1758) & $\mathrm{O}$ & o & o & o & 1 & 1 \\
\hline & Trachinotus marginatus Cuvier, 1832 & $\mathrm{O}$ & o & o & o & 1 & $\mathrm{O}$ \\
\hline & Uraspis secunda (Poey, 1860) & $\mathrm{O}$ & $\mathrm{o}$ & 1 & $\mathrm{O}$ & o & $\mathrm{O}$ \\
\hline \multirow{2}{*}{ CENTROPOMIDAE } & Centropomus parallelus Poey, 1860 & 1 & 1 & 1 & 1 & 1 & 1 \\
\hline & Centropomus undecimalis (Bloch, 1792) & $\mathrm{O}$ & 1 & $\mathrm{O}$ & 1 & $\mathrm{O}$ & 0 \\
\hline CHARACIDAE & $\begin{array}{l}\text { Hollandichthys multifasciatus (Eigenmann \& } \\
\text { Norris, 1900) }\end{array}$ & $\mathrm{O}$ & o & o & 1 & o & $\mathrm{O}$ \\
\hline \multirow{2}{*}{ CICHLIDAE } & Geophagus brasiliensis (Quoy \& Gaimard, 1824) & o & o & 1 & 1 & 1 & o \\
\hline & Oreochromis niloticus (Linnaeus, 1758 ) & $\mathrm{O}$ & o & 1 & o & o & o \\
\hline \multirow{5}{*}{ CLUPEIDAE } & Brevoortia pectinata (Jenyns, 1842) & $\mathrm{O}$ & o & o & o & 1 & $\mathrm{O}$ \\
\hline & Harengula clupeola (Cuvier, 1829) & 1 & 1 & 1 & 1 & 1 & 1 \\
\hline & Opisthonema oglinum (Lesueur, 1818) & 1 & o & o & 1 & 1 & 1 \\
\hline & Platanichthys platana (Regan, 1917) & 1 & o & o & o & o & O \\
\hline & Sardinella brasiliensis (Steindachner, 1879) & $\mathbf{O}$ & 1 & 1 & o & 1 & 1 \\
\hline CYNOGLOSSIDAE & Symphurus tessellatus (Quoy \& Gaimard, 1824) & 1 & 1 & 1 & 1 & 1 & 1 \\
\hline DACTYLOPTERIDAE & Dactylopterus volitans (Linnaeus, 1758 ) & $\mathrm{O}$ & o & o & o & 1 & 1 \\
\hline DIODONTIDAE & $\begin{array}{l}\text { Chilomycterus spinosus spinosus (Linnaeus, } \\
\text { 1758) }\end{array}$ & o & 1 & o & 1 & $\mathrm{o}$ & 1 \\
\hline ELOPIDAE & Elops saurus Linnaeus, 1766 & $\mathrm{O}$ & 1 & 1 & 1 & 1 & 1 \\
\hline \multirow{6}{*}{ ENGRAULIDAE } & Anchoa januaria (Steindachner, 1879) & $\bar{O}$ & o & 1 & 1 & 1 & 1 \\
\hline & Anchoa lyolepis (Evermann \& Marsh, 1900) & $\mathrm{O}$ & 1 & o & o & 1 & o \\
\hline & Anchoa marinii Hildebrand, 1943 & $\mathrm{O}$ & 1 & o & 1 & o & 1 \\
\hline & Anchoa spinifer (Valenciennes, 1848) & 1 & o & o & o & o & 1 \\
\hline & Anchoa tricolor (Spix \& Agassiz, 1829) & o & o & o & o & 1 & 1 \\
\hline & Anchovia clupeoides (Swainson, 1839) & 1 & $\mathrm{O}$ & o & 1 & o & 1 \\
\hline
\end{tabular}


Table 1. Continuation.

\begin{tabular}{|c|c|c|c|c|c|c|c|}
\hline Family & Species & BNO & LIM & ITA & RAT & CON & IND \\
\hline \multirow{4}{*}{ ENGRAULIDAE } & Anchoviella lepidentostole (Fowler, 1911) & $\mathrm{O}$ & O & $\mathrm{O}$ & 1 & $\mathrm{O}$ & 1 \\
\hline & Cetengraulis edentulus (Cuvier, 1829) & 1 & 1 & 1 & 1 & 1 & 1 \\
\hline & Engraulis anchoita Hubbs \& Marini, 1935 & o & o & o & o & 1 & 1 \\
\hline & Lycengraulis grossidens (Spix \& Agassiz, 1829) & $\mathrm{O}$ & 1 & 1 & 1 & 1 & 1 \\
\hline EPHIPPIDAE & Chaetodipterus faber (Broussonet, 1782) & 1 & 1 & 1 & 1 & O & 1 \\
\hline FISTULARIIDAE & Fistularia tabacaria Linnaeus, 1758 & o & o & o & o & 1 & $\mathrm{o}$ \\
\hline GEMPYLIDAE & Thyrsitops lepidopoides (Cuvier, 1832) & o & o & o & o & 1 & o \\
\hline \multirow{7}{*}{ GERREIDAE } & Diapterus auratus Ranzani, 1842 & o & o & o & 1 & o & 1 \\
\hline & Diapterus rhombeus (Cuvier, 1829) & 1 & 1 & 1 & 1 & 1 & 1 \\
\hline & Eucinostomus argenteus Baird \& Girard, 1855 & 1 & 1 & 1 & 1 & 1 & 1 \\
\hline & Eucinostomus gula (Quoy \& Gaimard, 1824) & 1 & 1 & 1 & 1 & 1 & 1 \\
\hline & Eucinostomus sp. & o & o & 1 & o & 1 & o \\
\hline & Eugerres brasilianus (Cuvier, 1830) & o & o & 1 & 1 & 1 & o \\
\hline & Ulaema lefroyi (Goode, 1874) & o & o & 1 & o & 1 & 0 \\
\hline \multirow{6}{*}{ GOBIIDAE } & Awaous tajasica (Lichtenstein, 1822) & o & o & o & o & 1 & o \\
\hline & Bathygobius soporator (Valenciennes, 1837) & o & o & 1 & 1 & 1 & o \\
\hline & Ctenogobius boleosoma (Jordan \& Gilbert, 1882) & o & o & o & o & 1 & o \\
\hline & $\begin{array}{l}\text { Ctenogobius shufeldti (Jordan \& Eigenmann, } \\
\text { 1887) }\end{array}$ & o & o & o & o & 1 & o \\
\hline & Ctenogobius stigmaticus (Poey, 1860 ) & o & o & o & o & 1 & o \\
\hline & Gobionellus oceanicus (Pallas, 1770) & 1 & 1 & 1 & 1 & 1 & 1 \\
\hline GYMNURIDAE & Gymnura altavela (Linnaeus, 1758) & $\mathrm{O}$ & 1 & 0 & 0 & 0 & 0 \\
\hline \multirow{6}{*}{ HAEMULIDAE } & Anisotremus surinamensis (Bloch, 1791) & o & o & o & 0 & 1 & 1 \\
\hline & Genyatremus luteus (Bloch, 1790) & o & o & 1 & o & o & o \\
\hline & Haemulon aurolineatum Cuvier, 1830 & o & 1 & o & o & 1 & o \\
\hline & $\begin{array}{l}\text { Haemulon steindachneri (Jordan \& Gilbert, } \\
\text { 1882) }\end{array}$ & o & o & o & o & 1 & o \\
\hline & Orthopristis ruber (Cuvier, 1830) & 1 & 1 & 1 & o & 1 & 1 \\
\hline & $\begin{array}{l}\text { Haemulopsis corvinaeformis (Steindachner, } \\
\text { 1868) }\end{array}$ & 1 & 1 & o & o & O & 1 \\
\hline \multirow{2}{*}{ HEMIRAMPHIDAE } & Hemiramphus brasiliensis (Linnaeus, 1758) & o & o & $\mathrm{O}$ & $\mathrm{O}$ & 1 & $\mathrm{O}$ \\
\hline & Hyporhamphus unifasciatus (Ranzani, 1841) & $\mathrm{O}$ & o & $\mathrm{O}$ & $\mathrm{o}$ & 1 & 1 \\
\hline HEPTAPTERIDAE & Rhamdia quelen (Quoy \& Gaimard, 1824) & o & $\mathrm{o}$ & o & 1 & 0 & $\mathrm{O}$ \\
\hline \multirow{5}{*}{ LUTJANIDAE } & Lutjanus analis (Cuvier, 1828) & O & o & $\bar{O}$ & $\mathrm{O}$ & 1 & 1 \\
\hline & Lutjanus cyanopterus (Cuvier, 1828) & o & o & o & o & 1 & o \\
\hline & Lutjanus jocu (Bloch \& Schneider, 1801) & o & o & o & o & 1 & o \\
\hline & Lutjanus sp. & o & o & o & o & 1 & o \\
\hline & Lutjanus synagris (Linnaeus, 1758) & $\mathrm{O}$ & 1 & o & o & $\mathrm{O}$ & $\mathrm{o}$ \\
\hline \multirow{3}{*}{ MONACANTHIDAE } & Aluterus schoepfii (Walbaum, 1792) & o & o & o & o & 1 & o \\
\hline & Monacanthus ciliatus (Mitchill, 1818) & o & o & o & o & 1 & o \\
\hline & Stephanolepis hispidus (Linnaeus, 1766) & 1 & 1 & o & $\mathrm{O}$ & 1 & 1 \\
\hline \multirow{3}{*}{ MUGILIDAE } & Mugil curema Valenciennes, 1836 & 1 & 1 & 1 & 1 & 1 & 1 \\
\hline & Mugil liza Valenciennes, 1836 & 1 & 1 & 1 & 1 & 1 & 1 \\
\hline & Mugil sp. & $\mathrm{o}$ & $\mathrm{o}$ & 1 & 1 & 1 & 1 \\
\hline MURAENIDAE & Gymnothorax ocellatus Agassiz, 1831 & 1 & 1 & o & o & $\mathrm{o}$ & 1 \\
\hline NARCINIDAE & Narcine brasiliensis (Olfers, 1831 ) & $\mathrm{O}$ & $\mathrm{O}$ & $\mathrm{O}$ & $\mathrm{O}$ & 1 & $\mathrm{O}$ \\
\hline OPHICHTHIDAE & Ophichthus gomesii (Castelnau, 1855) & 1 & 1 & 1 & 0 & 1 & 1 \\
\hline \multirow{7}{*}{ PARALICHTHYIDAE } & $\begin{array}{l}\text { Citharichthys arenaceus Ever- } \\
\text { mann \& Marsh, } 1900\end{array}$ & o & o & 1 & o & o & o \\
\hline & Citharichthys macrops Dresel, 1885 & o & o & o & 1 & $\mathrm{O}$ & 1 \\
\hline & Citharichthys spilopterus Günther, 1862 & 1 & 1 & 1 & 1 & 1 & 1 \\
\hline & Etropus crossotus Jordan \& Gilbert, 1882 & 1 & 1 & o & 1 & o & 1 \\
\hline & Etropus sp. & o & 1 & o & o & o & o \\
\hline & Paralichthys brasiliensis (Ranzani, 1842) & 1 & o & o & o & o & o \\
\hline & Paralichthys orbignyanus (Valenciennes, 1839) & o & 1 & o & o & o & o \\
\hline
\end{tabular}


Table 1. Continuation.

\begin{tabular}{|c|c|c|c|c|c|c|c|}
\hline Family & Species & BNO & LIM & ITA & RAT & CON & IND \\
\hline \multirow{2}{*}{ PARALICHTHYIDAE } & Paralichthys patagonicus Jordan, 1889 & O & O & $\mathrm{O}$ & $\mathrm{O}$ & $\mathrm{O}$ & 1 \\
\hline & Paralichthys sp. & $\mathrm{O}$ & O & $\mathrm{O}$ & $\mathrm{O}$ & 1 & $\mathrm{O}$ \\
\hline PLEURONECTIDAE & Oncopterus darwinii Steindachner, 1874 & o & 1 & $\mathrm{O}$ & o & o & $\mathrm{O}$ \\
\hline \multirow{2}{*}{ POECILIIDAE } & Phalloceros caudimaculatus (Hensel, 1868) & $\mathrm{O}$ & $\mathrm{O}$ & $\mathrm{O}$ & 1 & $\mathrm{O}$ & $\mathrm{O}$ \\
\hline & Poecilia sp. & $\mathrm{O}$ & $\mathrm{O}$ & 1 & $\mathrm{O}$ & 1 & $\mathrm{O}$ \\
\hline POLYNEMIDAE & Polydactylus virginicus (Linnaeus, 1758 ) & o & o & $\mathrm{O}$ & o & o & 1 \\
\hline POMACENTRIDAE & Abudefduf saxatilis (Linnaeus, 1758 ) & o & o & o & o & 1 & o \\
\hline POMATOMIDAE & Pomatomus saltatrix (Linnaeus, 1766) & o & 1 & 1 & o & 1 & 1 \\
\hline PRIACANTHIDAE & Heteropriacanthus cruentatus (Lacepède, 1801) & $\mathrm{o}$ & o & o & o & o & 1 \\
\hline \multirow{2}{*}{ PRISTIGASTERIDAE } & Chirocentrodon bleekerianus (Poey, 1867) & O & 1 & $\bar{O}$ & O & O & o \\
\hline & Pellona harroweri (Fowler, 1917) & 1 & 1 & o & o & 0 & 1 \\
\hline RHINOBATIDAE & Zapteryx brevirostris (Müller \& Henle, 1841) & 1 & o & o & o & o & o \\
\hline \multirow{19}{*}{ SCIAENIDAE } & Bairdiella ronchus (Cuvier, 1830) & o & 1 & 1 & o & o & 1 \\
\hline & Ctenosciaena gracilicirrhus (Metzelaar, 1919) & 1 & 1 & o & o & o & o \\
\hline & Cynoscion jamaicensis (Vaillant \& Bocourt, 1883) & 1 & o & 1 & 1 & o & 1 \\
\hline & Cynoscion leiarchus (Cuvier, 1830) & 1 & 1 & 1 & 1 & 1 & o \\
\hline & Cynoscion microlepidotus (Cuvier, 1830) & 1 & 1 & $\mathrm{O}$ & 1 & $\mathrm{O}$ & 1 \\
\hline & Isopisthus parvipinnis (Cuvier, 1830) & 1 & 1 & 1 & o & o & 1 \\
\hline & Larimus breviceps Cuvier, 1830 & o & o & $\mathrm{O}$ & o & o & 1 \\
\hline & Macrodon ancylodon (Bloch \& Schneider, 1801) & 1 & o & $\mathrm{O}$ & o & $\mathrm{O}$ & 1 \\
\hline & Menticirrhus americanus (Linnaeus, 1758) & 1 & 1 & o & 1 & o & 1 \\
\hline & Menticirrhus littoralis (Holbrook, 1847) & o & 1 & o & o & 1 & 1 \\
\hline & Micropogonias furnieri (Desmarest, 1823) & 1 & 1 & 1 & 1 & 1 & 1 \\
\hline & Odontoscion dentex (Cuvier, 1830) & 1 & o & o & o & o & o \\
\hline & Paralonchurus brasiliensis (Steindachner, 1875) & 1 & 1 & o & o & 1 & 1 \\
\hline & Pogonias cromis (Linnaeus, 1766) & o & o & 1 & 1 & o & 1 \\
\hline & Stellifer brasiliensis (Schultz, 1945) & 1 & 1 & o & o & o & o \\
\hline & Stellifer rastrifer (Jordan, 1889) & 1 & 1 & o & 1 & 1 & 1 \\
\hline & Stellifer sp. & o & 1 & o & o & o & o \\
\hline & Stellifer stellifer (Bloch, 1790) & o & 1 & o & o & o & 1 \\
\hline & Umbrina coroides Cuvier, 1830 & 1 & o & o & o & 1 & o \\
\hline SCOMBRIDAE & $\begin{array}{l}\text { Scomberomorus brasiliensis Collette, Russo \& } \\
\text { Zavala-Camin, } 1978\end{array}$ & $\mathrm{o}$ & o & o & o & o & 1 \\
\hline \multirow{2}{*}{ SCORPAENIDAE } & Scorpaena isthmensis Meek \& Hildebrand, 1928 & o & 1 & $\mathrm{O}$ & 0 & $\mathrm{O}$ & $\mathrm{O}$ \\
\hline & Scorpaena plumieri Bloch, 1789 & o & 1 & 0 & o & 1 & o \\
\hline \multirow{10}{*}{ SERRANIDAE } & Diplectrum formosum (Linnaeus, 1766) & o & o & o & o & 1 & o \\
\hline & Diplectrum radiale (Quoy \& Gaimard, 1824) & 1 & 1 & o & o & o & 1 \\
\hline & Epinephelus marginatus (Lowe, 1834) & o & 1 & o & o & 1 & o \\
\hline & Epinephelus morio (Valenciennes, 1828) & o & 1 & o & o & o & o \\
\hline & Hyporthodus niveatus (Valenciennes, 1828) & o & 1 & $\mathrm{O}$ & o & 1 & o \\
\hline & Mycteroperca acutirostris (Valenciennes, 1828) & o & 1 & o & o & 1 & o \\
\hline & Mycteroperca bonaci (Poey, 1860) & o & 1 & o & o & o & $\mathrm{o}$ \\
\hline & Mycteroperca microlepis (Goode \& Bean, 1879) & o & 1 & o & o & o & o \\
\hline & Mycteroperca sp. & o & 1 & o & o & 1 & o \\
\hline & Rypticus randalli Courtenay, 1967 & $\mathrm{o}$ & 1 & $\mathrm{O}$ & $\mathrm{O}$ & o & 0 \\
\hline \multirow{2}{*}{ SPARIDAE } & Archosargus rhomboidalis (Linnaeus, 1758) & 1 & 1 & $\mathrm{O}$ & 1 & 1 & 1 \\
\hline & Diplodus argenteus (Valenciennes, 1830) & $\mathrm{o}$ & $\mathrm{O}$ & $\mathrm{o}$ & $\mathrm{O}$ & 1 & 1 \\
\hline SPHYRAENIDAE & Sphyraena guachancho Cuvier, 1829 & o & 1 & o & $\mathrm{O}$ & o & 1 \\
\hline STROMATEIDAE & Peprilus paru (Linnaeus, 1758) & 1 & 1 & $\mathrm{O}$ & $\mathrm{O}$ & $\mathrm{O}$ & 1 \\
\hline \multirow{2}{*}{ SYNGNATHIDAE } & Hippocampus reidiI Ginsburg, 1933 & o & O & $\mathrm{O}$ & O & 1 & O \\
\hline & Syngnathus folletti Herald, 1942 & o & O & $\mathrm{O}$ & O & 1 & o \\
\hline
\end{tabular}


Table 1. Continuation.

\begin{tabular}{|c|c|c|c|c|c|c|c|}
\hline Family & Species & BNO & LIM & ITA & RAT & CON & IND \\
\hline SYNODONTIDAE & Synodus foetens (Linnaeus, 1766) & 1 & 1 & o & 1 & 1 & 1 \\
\hline \multirow{7}{*}{ TETRAODONTIDAE } & Lagocephalus laevigatus (Linnaeus, 1766) & 1 & $\overline{1}$ & $\bar{O}$ & $\bar{O}$ & $\overline{1}$ & 1 \\
\hline & Sphoeroides sp. & 1 & o & o & o & o & o \\
\hline & Sphoeroides greeleyi Gilbert, 1900 & 1 & 1 & o & o & o & 1 \\
\hline & $\begin{array}{l}\text { Sphoeroides pachygaster (Müller \& Troschel, } \\
\text { 1848) }\end{array}$ & o & 1 & $\mathrm{O}$ & o & o & $\mathrm{O}$ \\
\hline & Sphoeroides spengleri (Bloch, 1785) & 1 & 1 & o & o & 1 & 1 \\
\hline & Sphoeroides testudineus (Linnaeus, 1758) & 1 & 1 & 1 & 1 & 1 & 1 \\
\hline & Sphoeroides tyleri Shipp, 1972 & 1 & o & o & o & o & 1 \\
\hline TRICHIURIDAE & Trichiurus lepturus Linnaeus, 1758 & 1 & 1 & 1 & 1 & o & 1 \\
\hline \multirow{2}{*}{ TRIGLIDAE } & Prionotus nudigula Ginsburg, 1950 & o & o & o & o & o & 1 \\
\hline & Prionotus punctatus (Bloch, 1793) & 1 & 1 & o & 1 & 1 & 1 \\
\hline URANOSCOPIDAE & Astrocopus y-graecum. Cuvier, 1829. & o & o & $\mathrm{O}$ & o & $\mathrm{O}$ & 1 \\
\hline
\end{tabular}

The differences in richness between the sites and environments detected by PERMANOVA as well as species that have contributed to these differences can be observed graphically in the CAP. The canonical correlation of the two axes of the analysis was $\delta_{1}=$ 0.9934 and $\delta_{2}=0.9791$. There was a separation of the samples of each site, and those belonging to the same environment were grouped. The species Lagocephalus laevigatus, Prionotus punctatus, Chloroscombrus chrysurus, Selene setapinnis, Ctenosciaena gracilicirrhus, Menticirrhus americanus and Etropus crossotus were correlated with the bay samples (Figure 4). Orthopristis ruber and Stephanolepis hispidus were correlated with the bay and the beach. For the lagoon, there was correlation with $O$. bonariensis, $C$. shufeldti, A. tajasica, Ulaema lefroyi and Caranx hippos (Figure 4). For the mangroves, there was no clear association between species, but a graphical proximity between Oligoplites palometa, Geopha-

Table 2. PERMANOVA based on Bray-Curtis similarity of richness (square-root transformed). Factors: Environment=En, $\mathrm{Site}=\mathrm{Si}(\mathrm{En}), \mathrm{Season}=$ Se. $\mathrm{df}=$ degrees of freedom; MS=sum of squared means.

\begin{tabular}{ccccc}
\hline Source & df & MS & Pseudo-F & p(perm) \\
\hline En & 3 & 6523 & 3,4337 & 0,0217 \\
Se & 3 & 1,2231 & 0,57785 & 0,3117 \\
Si(En) & 2 & 1899,7 & 5,4663 & 0,0007 \\
En x Se & 9 & 376,58 & 1,0836 & 0,3953 \\
Res & 6 & 2085,1 & & \\
\hline
\end{tabular}

gus brasiliensis and L. grossidens (Figure 4). Among the samples of the lagoon and mangrove, there was correlation with the species Strongylura marina, Poecilia sp., Bathygobius soporator, M. liza and Sardinella brasiliensis (Figure 4).

When comparing the sites with the average taxonomic distinctness (Delta+) and variation in average taxonomic distinctness (Lambda+), all values of these indices for each site were within the $95 \%$ confidence interval, calculated in 1,000 simulations for each index (Figure 5a and 5b). For Delta+, the values for the Ratones Mangrove, North Bay, Índio Beach and Conceição Lagoon were on the average and

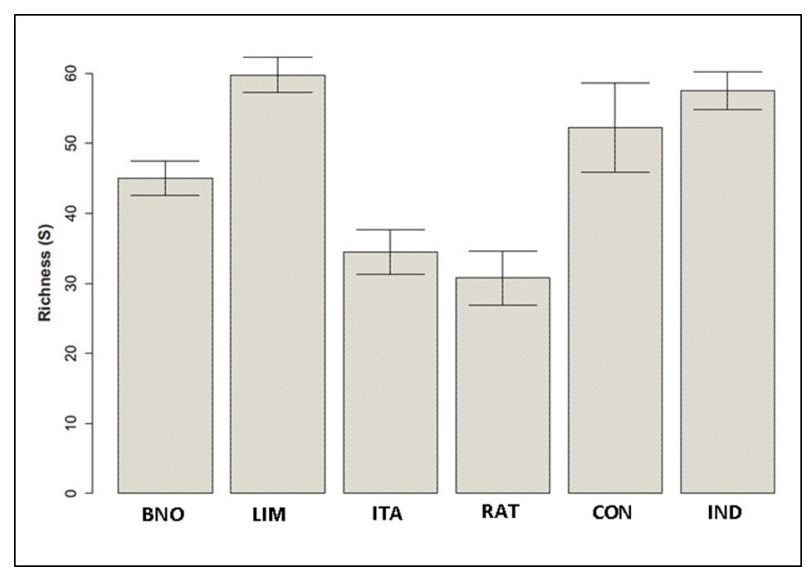

Figure 3. Mean species richness ( \pm standard error) in the North Bay (BNO), Saco dos Limões (LIM), Itacorubi Mangrove (ITA), Ratones Mangrove (RAT), Conceição Lagoon (CON) and Índio Beach (IND). 


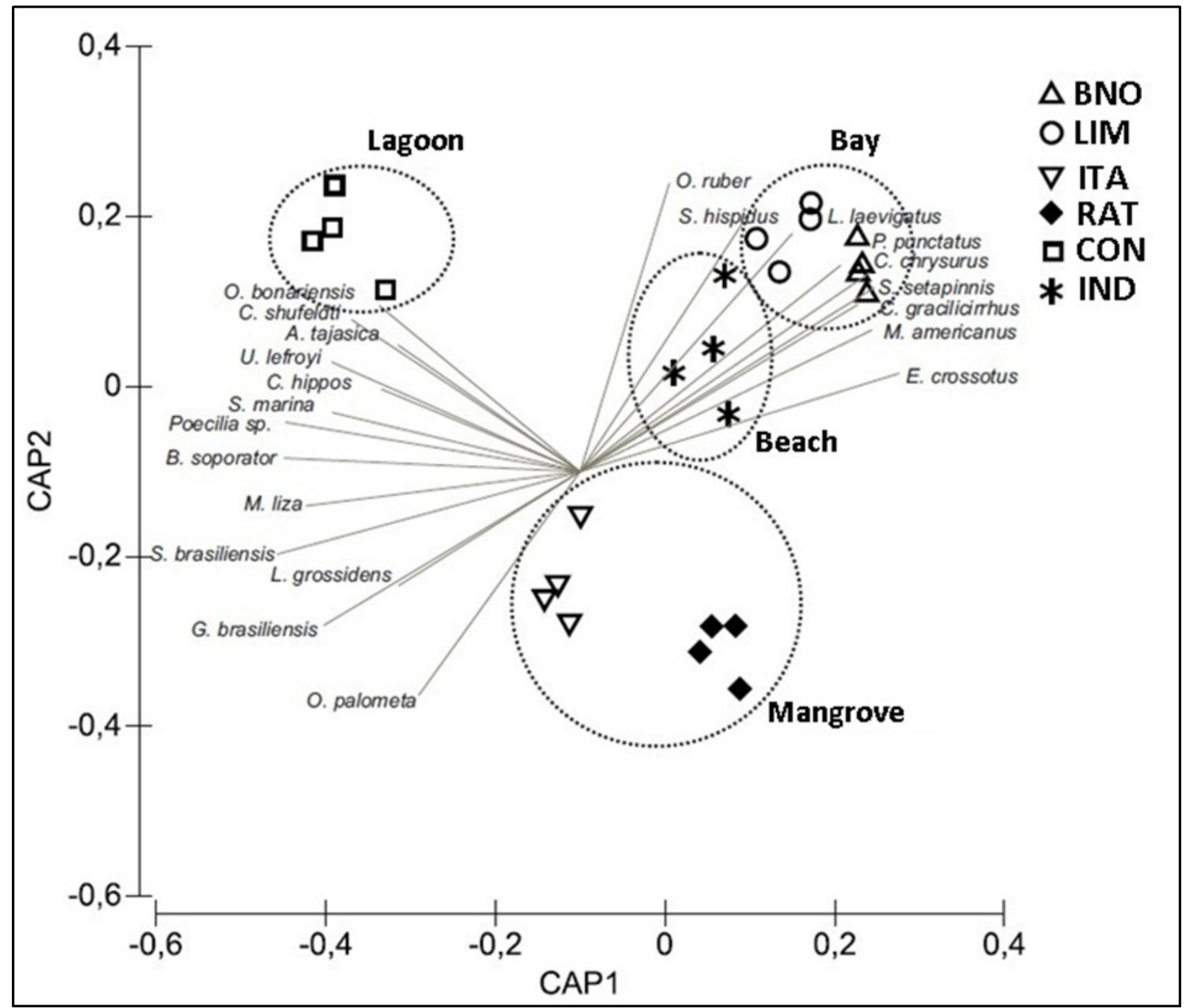

Figure 4. Canonical analysis of principal coordinates (CAP), with species that contributed most to the differences between the sites North Bay (BNO), Saco dos Limões (LIM), Itacorubi Mangrove (ITA), Mangrove Ratones (RAT), Conceição Lagoon (CON) and Índio Beach (IND) and environments (lagoon, bay, beach and mangrove). Vectors of species based on the Spearman correlation above 0.6 ( $p>0.6)$.

values of the Itacorubi Mangrove and Saco dos Limões were below the average (FIGURE 5a). Values for Lambda+ index were above the average for the North Bay and Saco dos Limões and below the average for the Índio Beach and Conceição Lagoon (Figure 5b). The mangroves, Ratones and Itacorubi, were close to the average. In the biplot graph, it can be observed that the values of the Ratones Mangrove, Conceição Lagoon and Índio Beach are within the ellipse of $95 \%$ probability of occurrence of 120 species, whereas the values of the Itacorubi Mangrove, Saco dos Limões and North Bay are within the ellipse of $95 \%$ probability of occurrence of 60 species (Figure $5 \mathrm{c}$ ). It is noteworthy the high values of both indices for the North Bay, whose Delta+ was similar to the values of the Conceição Lagoon, Ratones Mangrove and Índio Beach. However, for these latter sites, Lamb$\mathrm{da}+$ values were lower.

\section{Discussion}

In this study, the evaluation of species richness evidenced that the sampling was not sufficiently robust to survey all species of each site. The species accumulation curve based on the Jackknife index only reached the plateau with data of the Saco dos Limões and Itacorubi and Ratones mangroves. Thus, the sampling 

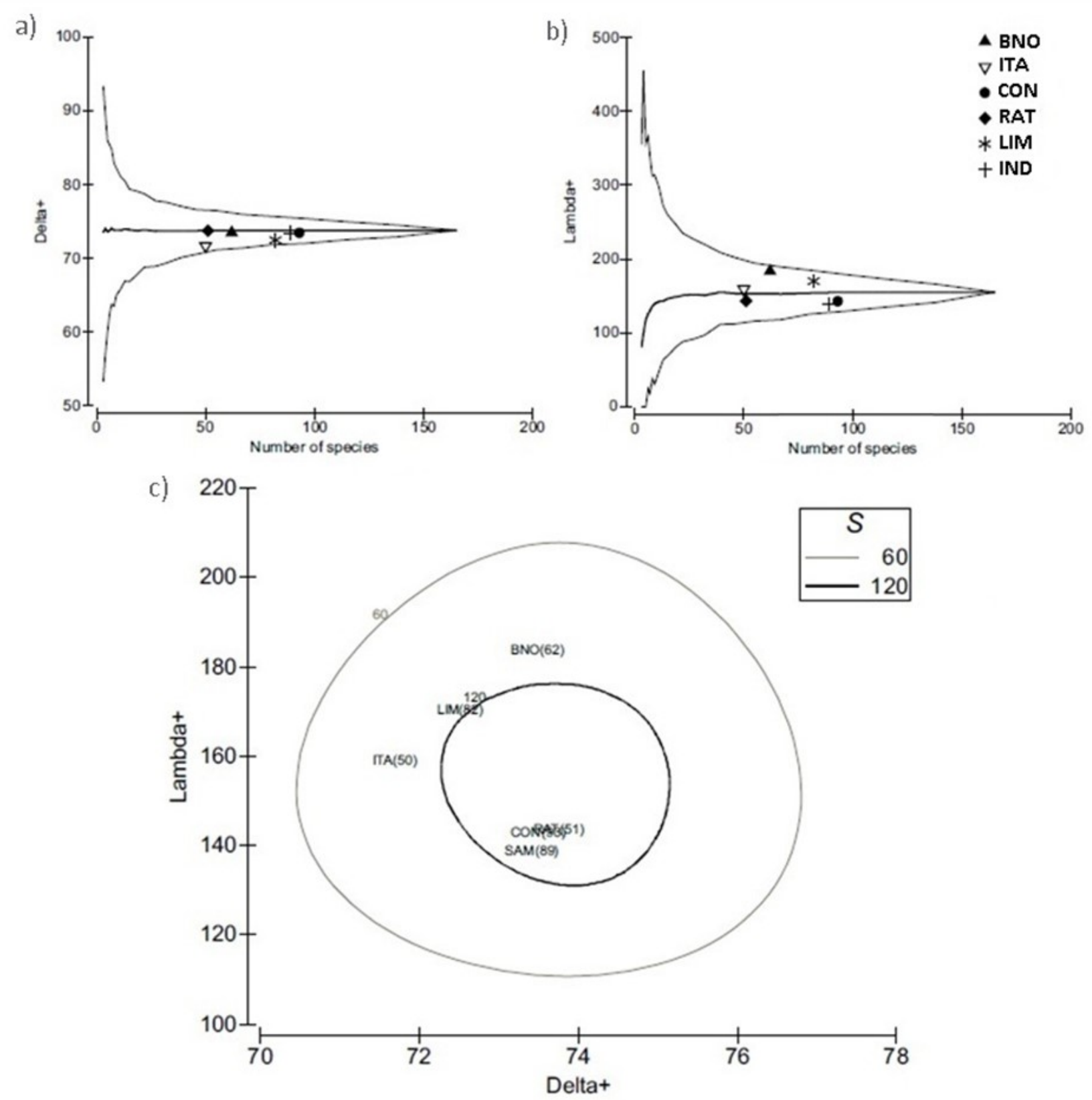

Figure 5. Average taxonomic distinctness (Delta + ) (a) and variation in average taxonomic distinctness $($ Lambda +) (b) calculated for the North Bay (BNO), Saco dos Limões (LIM), Itacorubi Mangrove (ITA), Ratones Mangrove (RAT), Conceição Lagoon (CON) and Índio Beach (IND). For both indices, the expected mean is represented by the central dotted line and the $95 \%$ confidence interval limit is given by the solid line, funnel-shaped. Biplot for values of Lambda+ and Delta+ (c). The ellipse represents the value of the $95 \%$ confidence interval of the probability of finding 60 and 120 species, respectively.

design was considered appropriate in these environments, either by the sampling effort or fishing gears used. In the case of other environments, the non-stabilization of the curve can have different explanations for each site.

In the North Bay, samplings were very dispersed, with low effort in each site. In the case of the Conceição Lagoon, despite the great number of sampling years, the difference between the samples, reflecting the different fishing methods may have influenced the construction of the curve. In relation to data of the Índio Beach, collected at the Índio Beach, the destabilization of the curve deserves attention. Sampling at this site was robust enough, and included the seasonal and diurnal variations. The fauna composition was also well diversi- 
fied with the presence of species of shallow areas and demersal species, probably due to the collection with a sampler in different tides, periods of the day and that captures fish with equal efficiency in the whole water column. Moreover, the mean number of species was high, just lower than the mean value for the Saco dos Limões.

As for PERMANOVA, the mean species richness between sites and between environments were significantly different, also highlighting the differences between the environments bay, beach, mangrove and lagoon. CAP evidenced which species were responsible for such differences. Two aspects have drawn attention in this analysis, the samples collected in geographically nearest sites were closer to each other and the separation of species associated with the axis 1 (CAP1), with species of shallower areas to the left, from the demersal species, to the right side. Between these two sets of species, there were two species $(O$. ruber and $S$. hispidus) associated with both the beach and with the bay. These are typically reef species and possibly use the evaluated areas at some stage of life. Thus, both PERMANOVA and CAP showed the differences between the environments.

In addition to the comparison of richness between sites and the environments, were calculated the Mean Taxonomic Distinction (Delta+ ou AvTD) e of Variation of Taxonomic Distinction (Lambda+ ou VarTD) were calculated to complement the results. Furthermore, the independence of these indices from the sampling effort compensates for differences between the sampling techniques used in each site (Clarke \& Warwick, 1994; Rogers et al, 1999). Using the list of species as reference, despite the differences in abundance and richness between sites, the taxonomic structure is similar between sampling sites, which supports the hypothesis that the assemblages are occurring in all sites and the differences are primarily related to the patterns of reproduction and recruitment of species and secondarily influenced by abiotic factors, especially the temperature and salinity. Thus, differences detected by PERMANOVA and evidenced by CAP show that despite the similarity in taxonomic structure between sites, some species predominate in each environment and each site.

Importantly, although the assemblages are taxonomically similar, not necessarily they are similar from an ecological point of view. Based on the concept that the assemblages are established by the interactions between populations over a spatial and temporal gradient in a certain geographic region (Ricklefs, 2008), it is expected that the alternation in the numerical dominance of different populations, even in situations of taxonomic similarity, which was observed in the studied areas (Cattani, 2015), assumes different ecological interactions, based on ecological niches occupied by these populations. In the case of the environments evaluated in the island of Santa Catarina, it is inferred that the differences in abundance possibly occurred due to the reproduction of the dominant species. Significant differences in total length of the most abundant species confirm this hypothesis (Cattani, 2015). A similar pattern was registered in estuarine areas of Australia (Blaber \& Blaber, 1980). It is likely that the species occur in many different environments (bay, mangrove, beach and lagoon) at different times of the year. An example of this common occurrence of species in different environments is the pattern observed for $G$. genidens. Higher mean values of total length (TL) were verified in the North Bay and lower mean values in the Ratones Mangrove (Cattani, 2015). Thus, it is suggested that this species has been occupying these environments at different ontogenetic stages, with younger individuals recruiting in the mangroves and migrating to deeper areas in adult stages. A similar result was also observed for C. edentulus, with longer lengths occurring in the North Bay and smaller lengths occurring in the Itacorubi Mangrove (Cattani, 2015).

Another factor that validates the hypothesis of the highest importance of ecological factors at the expense of environmental constraints is the fact that the island of Santa Catarina has no truly estuary, as is the case of other coastal regions of the Southeastern and Southern Brazil. There are only micro-estuaries, such 
as mangroves Itacorubi and Ratones. These two environments can be considered estuaries, despite the reduced scale, because according to the most classical definition (Day et al., 1989; Elliot \& Mclusky, 2002), estuaries are semienclosed coastal bodies of water with fresh water inflow, which dilutes the seawater. In the case of the North Bay and Saco dos Limões, which is located in the South Bay, there is a fresh water inflow. However, the salinity values remained relatively high, above 25 UPS, as observed for both sites (Cattani, 2015). In this sense, due to the low salinity gradient, the North Bay and Saco dos Limões have more characteristics of coastal than estuarine areas. However, these sites have common characteristics with the estuaries. Because of shallow depths, these sites have great importance for the post-recruitment stages of fish species. This was corroborated by high abundances of juveniles in all sites, despite the occurrence of adults (Cattani, 2015).

In general, the shallow areas, either shallow areas, beaches or mangroves, have high importance for the juvenile stages of fish and other aquatic organisms (Blaber \& Blaber, 1980; Blaber, 2002; Elliot \& Mclusky, 2002; Whitfield \& Elliot, 2002; Whitfield et al., 2012). In this sense, all the information analyzed in this study show that the island of Santa Catarina is highly important for the juvenile stages of several fish species. It is also important for the maintenance of some fish stocks, such as whitemouth croaker (Micropogonias furnieri), catfish (G. genidens) and especially mullet (M. liza).

Finally, for a better understanding of the different ways species use these sites and the real importance of the evaluated sites, future studies should focus on key species, such as $G$. genidens, C. edentulus, $M$. liza and $C$. spilopterus. The adoption of molecular tools, such as genetic markers, otolith microchemistry, and stable radioisotopes, are also very important in understanding the connectivity and trophic patterns in these environments.
ANDERSON, M. J.; GORLEY, R. N. \& CLARKE, K.R. 2008. PERMANOVA +for PRIMER: guide to software and statistical methods. PRIMER-E. Plymouth. 214 p.

BEGON, M.; TOWNSEND, C.R. \& HARPER, J.L. 2007. Ecology - From Individuals to Ecosystems. Fourth edition. Nova York, WileyBlackwell Publishing. 759 p.

BLABER, S.J.M. 2002. Fish in hot water: the challenges facing fish and fisheries research in tropical estuaries. J. of Fish Biol., 61: 1-20.

BLABER, S.J.M. \& BLABER, T.G. 1980. Factors affecting the distribution of juvenile estuarine and inshore Fish. J. of Fish Biol., 17: 143-162.

CARTAGENA, B. F. C.; HOSTIM-SILVA, M. \& SPACH, H. L. 2011. Distribuição espacial da ictiofauna demersal no Saco dos Limões (Baía Sul, Florianópolis, SC). Bioikos. 25(2): 117128.

CASSEMIRO, F.A.S. \& PADIAL, A.A. 2008. Teoria neutra da biodiversidade e biogeografia: aspectos teóricos, impactos na literatura e perspectivas. Oecol. Bras. (Impresso), 12: 706 -719 .

CASTILHOS, J.A. de \& GRÉ, J.C.R. 1997. Praias da Ilha de Santa Catarina: caracterização morfológica e problemas de erosão costeira. Aquit. Océan, 1(3): 107-113.

CATTANI, A.P. 2015. Ictiofauna de sistemas estuarinos e lagunares da Ilha de Santa Catarina. Pontal do Paraná, 212p. (Tese de Doutorado, Programa de Pós-graduação em Sistemas Costeiros e Oceânicos, Centro de Estudos do Mar, Universidade Federal do Paraná).

CERUTTI, R. L. 1996. Contribuição ao conhecimento da poluição doméstica na Baía Norte, área da Grande Florianópolis, SC. Florianópolis, 129p. (Dissertação de Mestrado, Programa de Pós-Graduação em Ecologia, Universidade Federal de Santa Catarina).

CLARKE, K. R. \& WARWICK, R. W. 1994. Change in marine communities: an aproach to statistical analysis and interpretation. Plymouth Marine Laboratory, Plymouth, 144 p.

CLARKE, K.R. \& GORLEY, R. N. 2006. PRIMER v6: user manual/tutorial. PRIMER-E, Plymouth. 192p.

\section{References}


COLWELL, R.K. \& CODDINGTON, J.A. 1994. Estimating terrestrial biodiversity through extrapolation. Philosop. Trans.: Biol. Scien., 345: 101-118.

DAY, J.W.; HALL, C.A.S.; KEMP, W.M. \& YÁÑEZ -ARANCIBIA, A. 1989. Estuarine Ecology. Nova York, Wiley-Blackwell Publishing, 558p.

ELLIOT, M. \& MCLUSKY, D.S. 2002. The need for definitions in understanding estuaries. Estu., Coast. and Shel. Scien., 55: 815-827.

ELLIOT, M.; WHITFIELD, A.K.; POTTER, I.C.; BLABER, S.J.M.; CYRUS, D.P.; NORDLIE, F.G. \& HARRISON, T.D. 2007. The guild approach to categorizing estuarine fish assemblages: a global review. Fish and Fisher., 8(3): 241-268.

HUBBELL, S.P. 2001. The neutral theory of biodiversity and biogeography. New Jersey. Princeton University Press, 396p.

HUTCHINSON, G.E. Populations studies - animal ecology and demography - concluding remarks. 1957. Col. Spri. Har. Symp. on Quantit. Biol., 22: 415-427.

MACIEL, M. L. T.; IBBOTSON, D. P. \& MAGALHÃES, A. R. M. 2010. Polidiariose em ostras Crassostrea gigas cultivadas na Praia da Ponta do Sambaqui, Florianópolis, Santa Catarina - Brasil. Braz. J. Vet. Res. An. Sci. 47 (5): $337-345$.

MPB. 2013. Relatório de impacto sobre o meio ambiente (RIMA) referente à implantação do contorno rodoviário de Florianópolis/SC. Available in: http://www.pmf.sc.gov.br/ arquivos/arquivos/

pdf/26_09_2013_14.57.58.5ofded9d83da5e 3c55bc9ec4a7f484fa.pdf Access in: 01 nov. 2017 .

MUEHE, D. \& GOMES JR., F. C. 1999. Batimetria e algumas considerações sobre a evolução geológica da lagoa da Conceição, Ilha de Santa Catarina. In: SIERRA DE LEDO, B. \& SORIANO-SIERRA, E. J. (ed.). O Ecossistema da Lagoa da Conceição. NEMAR/CCB/UFSC, SDM/FEPEMA, Florianópolis. 423p.

PASSOS, A.C.; CONTENTE, R. F.; ABBATEPAULO, F.V.; SPACH, H.L.; ARAUJO, C.C.V.; JOYEUX, J.C.; CARTAGENA, B.F.C. \& FÁVARO, L.F. 2013. Analysis of fish assemblage in sectors along a salinity gradient based on species, families and functional groups. Braz. J. of Ocean. (Impresso), 61: 251-264.

RIBEIRO, G.C.; SOETH, M.; ANDRADE, V.K.; SPACH, H.L. \& CATTANI, A. P. 2014. Nychthemeral and Monthly Occupation of the Fish Assemblage on a Sheltered Beach of Baía Norte, Florianópolis, Santa Catarina State, Brazil. Braz. J. of Ocean., 62: 209-223.

RICKLEFS, R.E. 2008. Disintegration of the Ecological Community. The Ameri. Nat., 172(6): 741-750.

ROGERS, S.I.; CLARKE, K.R. \& REYNOLDS, J.D. 1999. The taxonomic distinctness of coastal bottom-dwelling fish communities of the North-east Atlantic. J. of Anim. Ecol., 68(4): 769-782.

SIERRA de LEDO, B. 1997. Subsídios ecológicos para um plano de gestão integrada na zona costeira da Ilha de Santa Catarina. Aquit. Océan, 1(3): 9-28.

SIMONASSI, J. C.; DE LA CORTE, F. S. \& SORIANO-SIERRA, E. J. 1997. Variação temporal das concentrações de matéria orgânica e inorgânica circulantes entre o manguezal de Ratones e a baía Norte, Ilha de Santa Catarina, Brasil. Aquit. Océan. 1(3): 229-234.

SIMONASSI, J. C.; HENNEMANN, M. C.; TALGATTI D. \& MARQUES JR., A. N. 2010. Nutrient variations and coastal water quality of Santa Catarina Island, Brazil. Biotemas, 23: 211-223.

SORIANO-SIERRA, E.J. 1997. Fluxos de maré e interferências antrópicas à hidrodinâmica no interior de um manguezal naturalmente estressado: estudo de caso. Aquit. Océan, 1(3): 163-178.

SORIANO-SIERRA, E. \& SIERRA DE LEDO, B. (Eds.). 1998. Ecologia e gerenciamento do manguezal de Itacorubí. Florianópolis. NEMAR/CCB/UFSC. 396 p.

SOUZA-SIERRA, M. M. de; GIOVANELA, M.; AREND, K.; SZPOGANICZ, B. \& VIEIRA, S. M. 1997. Aspectos estruturais e físicoquímicos dos compostos húmicos de um manguezal severamente perturbado. Aquit. Océan. 1(3): 251-263.

WHITFIELD, A.K. \& ELLIOT, M. 2002. Fishes as 
indicators of environment and ecological changes within estuaries: a review of progress and some suggestions for the future. J. of Fish Biol., 61: 229-250.

WHITFIELD, A.K.; ELLIOT, M.; BASSET, A.; BLABER, S.J.M. \& WEST, R.J. Paradigms in estuarine ecology - A review of the Remane diagram with a suggested revised model for estuaries. Estu. Coast. and Shel. Scie., 97: 7890. 